\title{
PHYSICAL AND CHEMICAL PROPERTIES OF SOME SOILLESS MEDIA
}

\author{
Amr Sabahy ${ }^{*}$, Adel Bahnasawy**, Samir Ali** and \\ Zakaria El-Haddad**
}

\begin{abstract}
\end{abstract}
Soilless culture is a technique for crop production using no soil. Crops are grown in the nutrient solution or on a proper medium, therefore, soilless culture involves no work such tools or machines. But it needs additional costs for growing systems and chemical fertilizes. It offers earlier growth and higher yield. Lack of suitable soils, disease contamination after repeated use and the desire to apply optimal conditions for plant growth are leading to the worldwide trend of growing plant in media instead of soil characterization of these medium is not available in literature, therefore, the main aim of this work is to investigate the physical and chemical properties (light peat, vermiculite, perlite, dark peat, light peat and perlite (70:30) and light peat and vermiculite (50:50)) that meets the requirement of plant growth. These properties include: bulk density, moisture content, water holding capacity, porosity, pH, electrical conductivity (EC), total organic carbon, total organic matter, total nitrogen, total phosphorus, total potassium and $\mathrm{C} / \mathrm{N}$ ratio.

The results indicate that the bulk density value ranged from 95.7 to 125.8 $\mathrm{kg} \mathrm{m}^{-3}$, where, the highest value was recorded for perlite and the lowest value was recorded for dark peat. The moisture content values ranged from 23.30 to $32.50 \%$, where, the lowest value was recorded for perlite and the highest value was obtained for dark peat. The water holding capacity values ranged from 2.70 to $4.40 \mathrm{~g}$ water/g dry. The porosity values ranged from 87.0 to $92.0 \%$ for different soilless media. The average of $\mathrm{pH}, \mathrm{EC}$, organic carbon, organic matter, total nitrogen, total phosphorus and total potassium values was $6.15,0.28 \mathrm{dS} \mathrm{m}^{-1}, 19.93 \%$, $34.37 \%, 0.30 \%, 0.20 \%$ and $1.14 \%$, respectively for soilless media.

Keywords: chemical properties - physical properties - soilless media

\footnotetext{
*Researcher Assoc., Agric. Eng. Res. Inst., Agric. Res. Center, Egypt

**Prof. of Agric. Eng., Fac. of Agric., Benha Univ., Egypt
} 


\section{INTRODUCTION}

Tn horticultural crop production, the definition soilless cultivation encompasses all the systems that provide plant management in soilless conditions in which the supply of water and of minerals is carried out by nutrient solution, with or without a growing medium (e.g. rockwool, peat, perlite, pumice, coconut fibre, etc.). Soilless cultivation systems can be divided into: i) systems in the liquid medium, which do not have other media for the support of plant roots; and ii) systems in the solid medium, using a substrate to support the plants. The hydroponic system is made up of the systems in liquid medium and systems that use an inert substrate. In addition, the soilless substrate cultures utilization are classified into: i) open systems (while the nutrient solution that drains from the roots is not reused); and ii) closed systems (while the surplus nutrient solution is collected, corrected and put back into the system) (Winsor and Schwarz, 1990).

Substrates are defined as all those materials, used alone or mixed appropriately, that can provide the root system with better conditions (in terms of one or more aspects of plant growth) than those offered by agricultural soil (Noto, 1993). In soilless crops, the substrate replaces the soil because the natural soil is often poorly suited to cultivation due to chemical (reaction, nutrient availability, etc.), physical (density, structure, water retention, etc.), or biological (presence of pathogens, exhaustion, etc.) limitations, or because in this way it controls plant growth better. Plants grown in pots are characterized by a particularly high (and unbalanced) ratio between the aerial part and root, and by much bigger water, air and nutrient requirements than those that are recorded on the soil (and in the open field) where growth rates are slower and the volume of soil available for the roots is theoretically unlimited. To meet these requirements, we need to use substrates that, alone or in a mixture, ensure chemical, physical and biological conditions that are optimal and stable in time. To do this, different types of materials have long been traditionally used in horticulture and in the nursery industry. Over the last few decades there has been, on the one hand, a significant increase in the number of materials used, arising from industrial processes, to be used with or in replacement of traditional materials and, 
secondly, there has been a growing use of substrates of cultivation (Gruda, 2012).

The substrate must perform different functions: i) support the plant and provide air, water and nutrients to the roots; ii) it must not contain pathogens; and iii) should not be phytotoxic. Any organic or inorganic material can be used as a substrate, provided that it meets the above conditions. There is no universal substrate or mixture that is valid for all species and in all situations of cultivation. It is, therefore, appropriate to carefully select the individual materials according to the different conditions in which they will be used: the environment, species to be cultivated, cultivation phase (germination, rooting of cuttings, plant production, plant breeding) and system of cultivation (Di Lorenzo, et al. 2013).

Physical, chemical and biological substrate properties can change and deteriorate with time and use, which may affect both crop management and behaviour. Mechanical degradation of substrates can alter the pore structure, which may in turn affect retention and movement of nutrient solution and root aeration (Orozco and Marfà, 1995; Giuffrida et al., 2007; Verhagen, 2009).

Lack of suitable soils, disease contamination after repeated use and the desire to apply optimal conditions for plant growth are leading to the worldwide trend of growing plant in media instead of soil characterization of these medium is not available in literature, therefore, the main aim of this work is to investigate the physical and chemical properties that meets the requirement of plant growth. These properties include: bulk density, moisture content, water holding capacity, porosity, $\mathrm{pH}, \mathrm{EC}$, total organic carbon, total organic matter, total nitrogen, total phosphorus, total potassium and $\mathrm{C} / \mathrm{N}$ ratio.

\section{EXPERIMENTAL PROCEDURES}

The experiment was carried out at Sekem Company at the Belbeies, ElSharkia Governorate, Egypt.

Six different types of soilless media were obtained by mixing light peat, dark peat, vermiculite and perlite at different ratios to form:

1- $\mathrm{M}_{1}$, light peat 
2- $\mathrm{M}_{2}$, vermiculite

3- $\mathrm{M}_{3}$, perlite

4- $\mathrm{M}_{4}$, dark peat

5- $\mathrm{M}_{5}$, light peat and perlite (70:30)

6- $\mathrm{M}_{6}$, light peat and vermiculite (50:50)

Samples were placed in polyethylene bags and transferred to the laboratory for analysis and properties measurements.

\section{Measuring Instruments and Procedures:}

\section{- Physical properties:}

The physical properties include: bulk density, moisture content, water holding capacity and porosity.

\section{1- Moisture contents (MC):}

Moisture content (wet basis) throughout this study was measured by drying at $105 \circ \mathrm{C}$ for approximately $24 \mathrm{~h}$ or at constant weight (ASAE Standard, 1998).

\section{2- Water holding capacity (WHC):}

A wet sample of known initial moisture content was weighed $\left(\mathrm{W}_{\mathrm{i}}\right)$ and placed in a beaker. After soaking in water for 1-2 days and draining excess water through Whatman \#2filter paper, the saturated sample was weighed again $\left(\mathrm{W}_{\mathrm{s}}\right)$. The amount of water retained by dry sample was calculated as the WHC. The water holding capacity (g water/g dry material) is calculated as (Ahn et al., 2008):

$$
W H C=\frac{\left\{\left(W_{s}-W_{i}\right)+M C \times W_{i}\right\}}{\left\{(1-M C) \times W_{i}\right\}}
$$

Where:

$\mathrm{W}_{\mathrm{i}}$ is the initial weight of sample $(\mathrm{g})$

$\mathrm{W}_{\mathrm{s}}$ is the saturated weight of sample $(\mathrm{g})$

$\mathrm{MC}$ is the initial moisture content of sample (decimal)

\section{3- Bulk density and porosity}

Bulk density was measured using an approximately 10 liters volume container. The container was filled with material, and then the material was slightly compacted to ensure absence of large void spaces. The bulk density was calculated by dividing the weight of the material by the volume of material in the container. 
Soilless media porosity $\left(\varepsilon_{\mathrm{a}}\right)$ was determined using the known density of water $\left(\rho_{\mathrm{w}} ; 1000 \mathrm{~kg} \mathrm{~m}^{-3}\right)$ and estimated densities of organic matter $\left(\rho_{\mathrm{om}}\right.$; $\left.1600 \mathrm{~kg} \mathrm{~m}^{-3}\right)$, and ash $\left(\rho_{\text {ash }} ; 2500 \mathrm{~kg} \mathrm{~m}^{-3}\right)$, as well as the moisture content and bulk densities of the sample (Raman, 1995). If the moisture content (MC), dry matter (DM), organic matter (OM), and wet bulk density $\left(\rho_{\mathrm{wb}}\right)$ of samples are known, the porosity can be calculated using the following equation:

$$
\varepsilon_{a}=1-\rho_{w b}\left(\frac{M C}{\rho_{w}}+\frac{D M \cdot O M}{\rho_{\text {om }}}+\frac{D M \cdot(1-O M)}{\rho_{\text {ash }}}\right) \times 100
$$

Where:

$\varepsilon_{\mathrm{a}}$ is the porosity $(\%)$

$\rho_{\mathrm{wb}}$ is the wet bulk density $\left(\mathrm{kg} \mathrm{m}^{-3}\right)$

$\rho_{\mathrm{w}}$ is the density of water $\left(\mathrm{kg} \mathrm{m}^{-3}\right)$

$\rho_{\mathrm{om}}$ is the density of organic matter $\left(\mathrm{kg} \mathrm{m}^{-3}\right)$

$\rho_{\text {ash }}$ is the density of ash $\left(\mathrm{kg} \mathrm{m}^{-3}\right)$

$\mathrm{MC}$ is the moisture content (decimal)

$\mathrm{DM}$ is the dry matter (decimal)

$\mathrm{OM}$ is the organic matter (decimal)

\section{- Chemical properties:}

The chemical properties include: $\mathrm{pH}, \mathrm{EC}$, total organic carbon, total organic matter, total nitrogen, total phosphorus, total potassium and $\mathrm{C} / \mathrm{N}$ ratio.

Electrical conductivity was measured using EC meter (Model ORION 105 - Range $0-199.99 \mathrm{dS} \mathrm{m}^{-1} \pm 0.01$, USA). $\mathrm{pH}$ was measured using pH meter (Model ORION 230A - Range $-2-19.99 \pm 0.01$, USA). Total organic carbon (TOC) by the dry combustion method at $540{ }^{\circ} \mathrm{C}$ for $4 \mathrm{~h}$ according to Abad et al. (2002). Total organic matter was measured by combustion at $550{ }^{\circ} \mathrm{C}$ for $8 \mathrm{~h}$ according to TMECC (2001) and total nitrogen (TN) by Kjeldahl digestion (Bremmer and Mulvaney, 1982). Potassium (K) was determined by atomic absorption and phosphorus (P) was determined colorimetrically following the Murphy and Riley (1962) method. 


\section{RESULTS AND DISCUSSION}

\subsection{Physical properties:}

Table (1) and figures (1, 2, 3 and 4) show the physical properties (bulk density, moisture content, water holding capacity and porosity) of the different types of soilless media (light peat, dark peat, vermiculite, perlite, light peat and perlite (70:30) and light peat and vermiculite (50:50)).

The results indicate that the bulk density value ranged from 95.7 to 125.8 $\mathrm{kg} \mathrm{m}^{-3}$ for different soilless types. The highest value of bulk density $\left(125.8 \mathrm{~kg} \mathrm{~m}^{-3}\right)$ was found for perlite and the lowest value of bulk density $\left(95.7 \mathrm{~kg} \mathrm{~m}^{-3}\right)$ was found for dark peat. These results agreed with those obtained by (Pardossi, 2011).

The dry bulk densities for most growing media are 3-20 times lower for most soils (soils are about $1500 \mathrm{~kg} \mathrm{~m}^{-3}$, for rooting media). For a given material, an increase in bulk density is associated with decrease in total pore space and thus affects growth mainly through the effects of reduced free pore space. A decrease in total pore space will often decrease oxygen transport and decrease root penetration. A decrease in total pore space may also increase the water retention as pore diameters decrease, which is to say that loss of physical structure often results in an increase in water retention of the remaining material. Interpretations of the influence of bulk density on growth may be improved by focussing on the individual effects of reduced pore space rather than on the broader concept of bulk density (Michael and Lieth, 2008).

Table (1): Physical properties of different soilless media.

\begin{tabular}{|l|c|c|c|c|c|c|}
\hline \multirow{2}{*}{\multicolumn{1}{|c|}{ Properties }} & \multicolumn{7}{|c|}{ Soilless Types } \\
\cline { 2 - 7 } & $\mathrm{M}_{1}$ & $\mathrm{M}_{2}$ & $\mathrm{M}_{3}$ & $\mathrm{M}_{4}$ & $\mathrm{M}_{5}$ & $\mathrm{M}_{6}$ \\
\hline Bulk density $\left(\mathrm{kg} \mathrm{m}^{-3}\right)$ & 108.5 & 119.7 & 95.7 & 125.8 & 104.66 & 114.1 \\
\hline Moisture content (\%) & 30.7 & 26.8 & 23.3 & 32.5 & 28.48 & 28.75 \\
\hline $\begin{array}{l}\text { Water holding } \\
\text { capacity (g water/g } \\
\text { dry sample) }\end{array}$ & 3.9 & 4.4 & 2.7 & 3.6 & 3.54 & 4.15 \\
\hline Porosity (\%) & 91 & 88 & 93 & 87 & 91 & 89 \\
\hline
\end{tabular}

$\mathrm{M}_{1}$ light peat $\mathrm{M}_{2}$ vermiculite $\mathrm{M}_{3}$ perlite $\mathrm{M}_{4}$ dark peat $\mathrm{M}_{5}$ light peat and perlite (70:30) $\mathrm{M}_{6}$ light peat and vermiculite (50:50) 
The moisture content values ranged from 23.30 to $32.50 \%$ for different soilless types. The lowest value of moisture content $(23.30 \%)$ was found for perlite and the highest value of moisture content $(32.50 \%)$ was obtained for dark peat.

It could be seen that the bulk density of soilless media increases with increasing the moisture content of soilless media. It increases from 95.7 to $125.8 \mathrm{~kg} \mathrm{~m}^{-3}$ when the moisture content increased from 23.30 to 32.50 $\%$.

Regarding the water holding capacity, it ranged from 2.70 to $4.40 \mathrm{~g}$ water/g dry sample for different soilless types. The lowest value of water holding capacity (2.70 g water/g dry sample) was found for perlite and the highest value of water holding capacity ( $4.40 \mathrm{~g}$ water/g dry sample) was found for vermiculite.

Water holding capacity of soilless media are usually 10-100 times lower than the common values for soil $(10-100 \mathrm{kPa})$. The results are indicative of the ease of the uptake of water - and nutrition - by plants as well as the wetness in various growing systems. Growth is highest at low water retention forces, but very low water retention forces are sometimes avoided, for example, when the amount of air-filled pores becomes too low for proper oxygen transport. The air content recommendations for optimal growth are found in kipp et al., 2001. Water retention forces high enough to decrease the fresh weight growth may actually be desirable, for example to create denser, that is better quality pot plants and in transplant production, when hardy plants are preferred by the growers.

The porosity values ranged from 87.0 to $93.0 \%$ for different soilless types. The lowest value of the porosity $(87.0 \%)$ was found for perlite and the highest value of the porosity $(93.0 \%)$ was found for dark peat. The porosity depends on bulk density and moisture content of soilless media. The porosity decreased with increasing bulk density and moisture content. The results indicate that the porosity of soilless media decreased from 93.0 to $87.0 \%$ when the bulk density increased from 125.8 to 119.7 $\mathrm{kg} \mathrm{m}^{-3}$ with decreasing the moisture content from 32.5 to $26.8 \%$. These results agreed with those obtained by Pardossi (2011). 


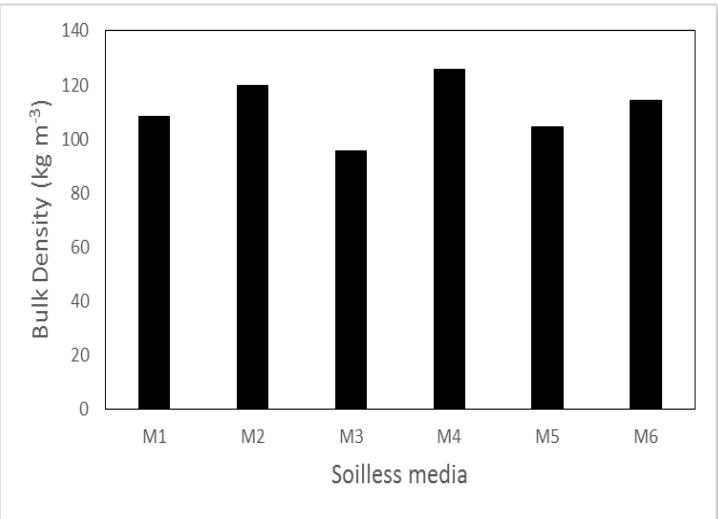

Fig. (1): Bulk density for different soilless media

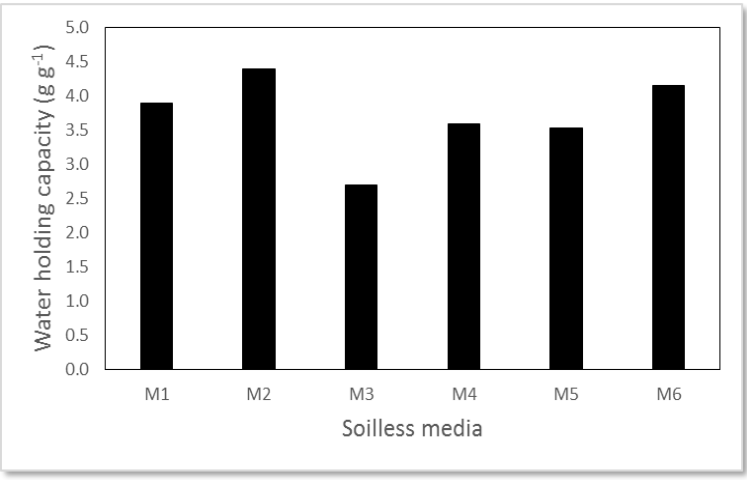

Fig. (3): Water holding capacity for different soilless media

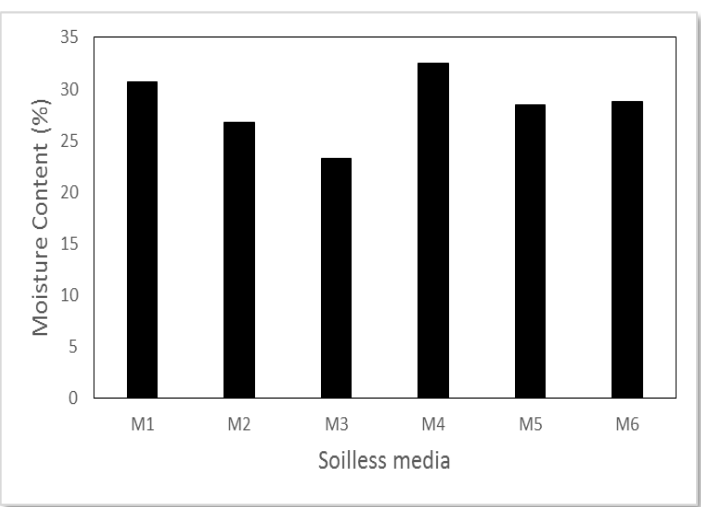

Fig. (2): Moisture content for different soilless media

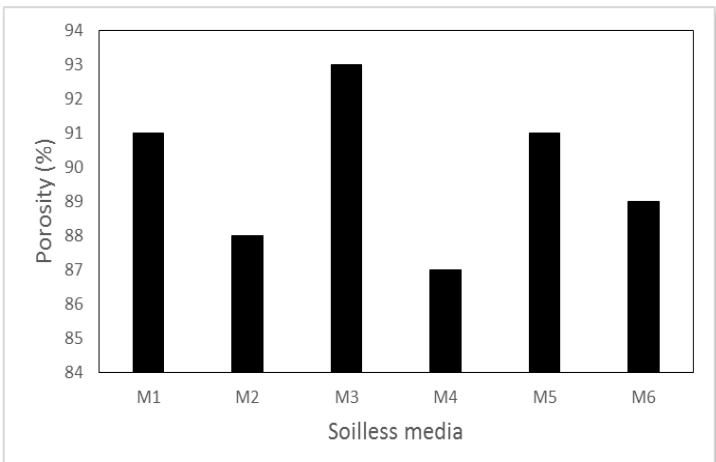

Fig. (4): Porosity for different soilless media 
$\mathrm{C} / \mathrm{N}$ ratio) of different types of soilless media (light peat, dark peat, vermiculite, perlite, light peat and perlite (70:30) and light peat and vermiculite (50:50)). It could be seen that the $\mathrm{pH}$ value ranged from 5.2 to 7.8 for different soilless media types. The highest value of $\mathrm{pH}$ (7.8) was found for vermiculite, while, the lowest value of $\mathrm{pH}$ (5.2) was obtained for light peat. This $\mathrm{pH}$ range is in the optimum range for growing media as mentioned by Bunt (1988).

The EC values ranged from 0.005 to $0.8 \mathrm{dS} \mathrm{m}^{-1}$ for different soilless media types. The highest value of EC $\left(0.8 \mathrm{dS} \mathrm{m}^{-1}\right)$ was found for dark peat and the lowest value of EC $\left(0.005 \mathrm{dS} \mathrm{m}^{-1}\right)$ was determined for the perlite.

Regarding the total organic carbon results, it was found that it ranged from 0.00 to $38.51 \%$ for different soilless media types under study. The total organic carbon was $0.0,0.64,36.42,38.51,25.49$ and $18.53 \%$ for perlite, vermiculite, light peat, dark peat light peat and perlite (70:30) and light peat and vermiculite (50:50), respectively.

Table (2): Chemical properties of different soilless media.

\begin{tabular}{|l|c|c|c|c|c|c|}
\hline \multirow{2}{*}{\multicolumn{1}{c|}{ Properties }} & \multicolumn{7}{|c|}{ Soilless Types } \\
\cline { 2 - 8 } & $\mathrm{M}_{1}$ & $\mathrm{M}_{2}$ & $\mathrm{M}_{3}$ & $\mathrm{M}_{4}$ & $\mathrm{M}_{5}$ & $\mathrm{M}_{6}$ \\
\hline $\mathrm{pH}$ & 5.2 & 7.8 & 6.2 & 5.7 & 5.5 & 6.5 \\
\hline $\mathrm{EC}\left(\mathrm{dS} \mathrm{m}^{-1}\right)$ & 0.28 & 0.18 & 0.005 & 0.8 & 0.20 & 0.23 \\
\hline Organic matter (\%) & 62.8 & 1.1 & 0 & 66.4 & 43.96 & 31.95 \\
\hline Organic Carbon (\%) & 36.42 & 0.64 & 0 & 38.51 & 25.49 & 18.53 \\
\hline Total Nitrogen (\%) & 0.51 & 0.004 & 0 & 0.68 & 0.36 & 0.26 \\
\hline Total Phosphorus (\%) & 0.03 & 0.01 & 0 & 1.1 & 0.021 & 0.02 \\
\hline Total potassium (\%) & 0.13 & 0.003 & 3.2 & 2.4 & 1.051 & 0.067 \\
\hline C/N Ratio & 71.41 & 160 & 0 & 56.63 & 71.41 & 72.10 \\
\hline
\end{tabular}

$\mathrm{M}_{1}$ light peat $\mathrm{M}_{2}$ vermiculite

$\mathrm{M}_{5}$ light peat and perlite (70:30) (50:50)

ppm $=640 \mathrm{dS} \mathrm{m}^{-1}$

The total organic matter values ranged from 0.00 to $66.40 \%$ for different soilless media types. The total organic matter was $0.0,1.10,62.80,38.51$, 
43.96 and $31.95 \%$ for perlite, vermiculite, light peat, dark peat, light peat and perlite (70:30) and light peat and vermiculite (50:50), respectively. The total nitrogen values ranged from 0.00 to $0.68 \%$ for different soilless types under study. The total nitrogen values was $0.00,0.004$, $0.68,0.51,0.36$ and $0.26 \%$ for perlite, vermiculite, light peat, dark peat, light peat and perlite (70:30) and light peat and vermiculite (50:50), respectively.

The total phosphorus and potassium values ranged from 0.0 to 1.1 and 0.003 to $3.20 \%$, respectively, for different soilless media. The lowest value of total phosphorus $(0.0 \%)$ was found for perlite and the highest value of total phosphor $(1.1 \%)$ was found for dark peat. The lowest value of total potassium $(0.003 \%)$ was found for light peat and the highest value of total potassium $(3.20 \%)$ was found for perlite.

Regarding the $\mathrm{C} / \mathrm{N}$ ratio, it ranged from 0:0 to 160:1 for different soilless types. The lowest value of $\mathrm{C} / \mathrm{N}$ ratio $(0: 0)$ was found for perlite and the highest value of $\mathrm{C} / \mathrm{N}$ ratio (160:1) was found for vermiculite.

\section{CONCLUSIONS}

An experimental study was carried out successively to determine the physical and chemical properties of different soilless media. The obtained results indicate that the bulk density value ranged from 95.7 to $125.8 \mathrm{~kg} \mathrm{~m}^{-3}$. The moisture content values ranged from 23.30 to $32.50 \%$. The water holding capacity values ranged from 2.70 to $4.40 \mathrm{~g}$ water/g dry. The porosity values ranged from 87.0 to $92.0 \%$ for different soilless media. The $\mathrm{pH}$ value ranged from 5.2 to 7.8 and $\mathrm{EC}$ values ranged from 0.0 to $0.28 \mathrm{dS} \mathrm{m}^{-1}$ for different soilless media. The total organic carbon values ranged from 0.0 to $38.51 \%$. The total organic matter values ranged from 0.0 to $66.40 \%$. The total nitrogen values ranged from 0.0 to $0.68 \%$. The total phosphorus and total potassium values ranged from 0.0 to $1.1 \%$ and 0.003 to $3.2 \%$, respectively, for different soilless media. The $\mathrm{C} / \mathrm{N}$ ratio values ranged from 0 to $160: 1$.

\section{REFERENCES}

Abad, M., P. Noguera, R. Puchades, A. Maquieira and V. Noguera (2002). Physico-chemical and chemical properties of some coconut coir dusts for use as a peat substitute for containerised ornamental plants. Bioresour. Technol. 82: $241-245$. 
Ahn, H. K., T. L. Richard and T. D. Glanville (2008). Laboratory determination of compost physical parameters for modeling of airflow characteristics. Waste Management, 28: 660 - 670.

ASAE Standards (1998). ASAE S353 DEC97. Moisture measurementmeat and products. Adopted and published by ASAE 1998, St. Josebh, MI: ASAE. $45^{\text {th }}$ Edition P552.

Bremmer, J. M. and C. S. Mulvaney (1982). Nitrogen-total. In: Page, A.L., Miller, R.H., Keeney, D.R. (Eds.), Methods of Soil Analysis, Part 2. Chemical and Microbiological Properties, second ed., Agronomy series No. 9 ASA, SSSA, Madison, WI, pp. 595-624.

Bunt, A. C. (1988). Media and Mixes for Container-Grown Plants, second ed. Unwin Hyman Ltd., London, UK.

Di Lorenzo, R., A. Pisciotta, P. Santamaria and V. Scariot (2013). From soil to soil-less in horticulture: quality and typicity. Italian Journal of Agronomy, 8: 255 - 260.

Giuffrida, F., C. Leonardi and O. Marfà (2007). Substrate reuse in tomato soilless cultivation. Acta Hortic., 801: 1577 - 1582.

Gruda, N. (2012). Sustainable peat alternative growing media. Acta Hortic., 927: 973 - 979.

Hanlon, E. A. (2012). Soil pH and electrical conductivity: a count extension soil laboratory manual. http://edis:ifas.ufl.edu.

Kipp, J. A., G. Wever and C. De Kreij (2001). International Substrate Manual. Elsevier.

Michael, R. and J. H. Lieth (2008). Soilless culture: Theory and Practice. $1^{\text {st }}$ Edition. Elsevier.

Murphy, J. and J. P. Riley (1962). A modified single solution method for determination of phosphate in natural waters. Anal. Chem. Acta 27: $31-36$.

Noto, G. (1993). I substrati di coltivazione. Tecn. Agric., 45: 3 - 39.

Orozco, R. and O. Marfà, (1995). Granulometric alteration air-entry potential and hydraulic conductivity in perlites used in soilless cultures. Acta Hortic. 408: 147-161.

Pardossi, A., G. Carmassi, C. Diara, L. Incrocci, R. Maggini and D. Massa (2011). Fertigation and Substrate Management in Closed Soilless Culture. Dipartimento di Biologia delle Piante Agrarie, University pf Pisa, Pisa, Italy. 
Raman, S., (1995). Food Properties Handbook. CRC Press, Boca Raton, Florida.

Rayment, G. E. and F. R. Higginson (1992). Australian Laboratory Handbook of Soil and Water Chemical Methods. Inkata Press, Melbourne.

Test Methods for the Examination of Composting and Compost (TMECC) (2001). The Composting Council Research and Education Foundation.

Verhagen, J. B. (2009). Stability of growing media from a physical, chemical and biological perspective. Acta Hortic., 867: 135 -142.

Winsor, G. W. and M. Schwarz (1990). Soilless culture for horticulture crop production. FAO Plant Production and Protection Paper, Publication No. 101, Rome, Italy.

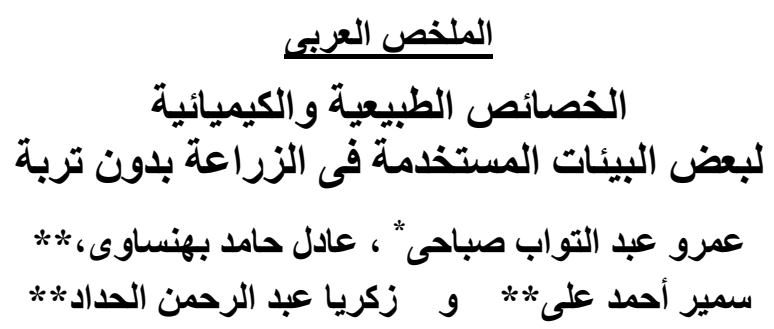

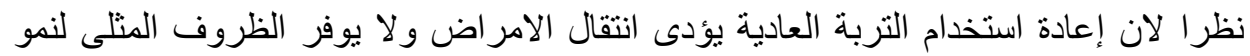

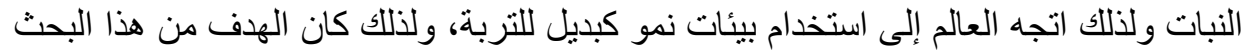

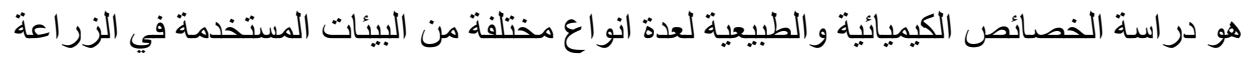

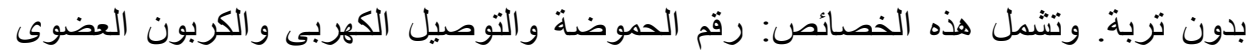

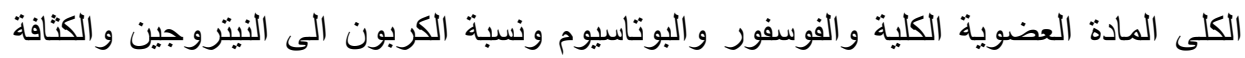
الظاهرية و المحتوى الرطوبى و القدرة على الاحتفاظ بالماء و المسامية.

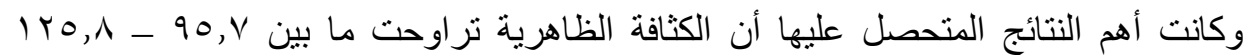

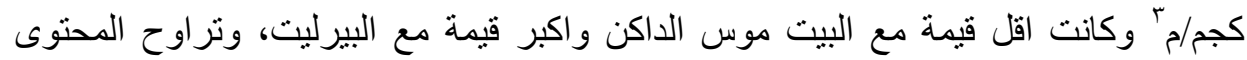

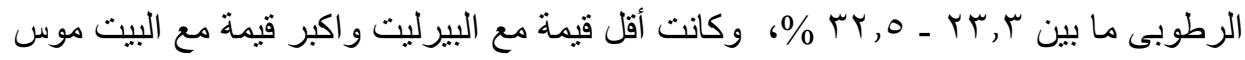

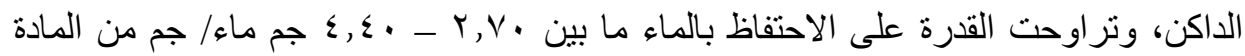

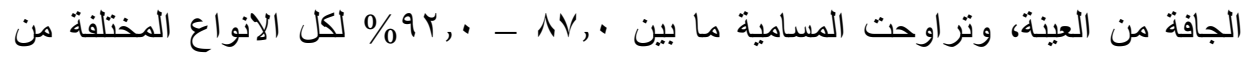

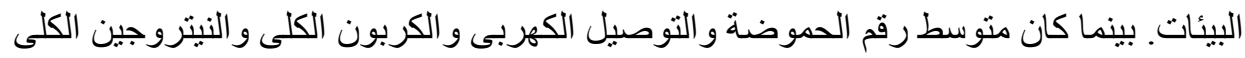

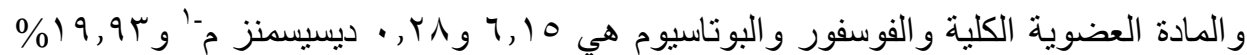

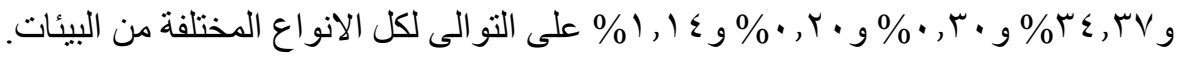

* باحث مساعد ـ معها بحوث الهندة الزراعية ـ مركز البحوث الزراعية ** أستاذ الهندسة الزراعية ـ كلية الزراعة بمشتهر - جامعة بنها 